National and Global Petroleum Assessment

\title{
Assessment of Undiscovered Oil and Gas Resources in the Tindouf Basin Province, North Africa, 2018
}

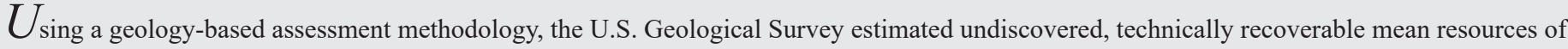
2.6 billion barrels of oil and 123.9 trillion cubic feet of gas in the Tindouf Basin Province of North Africa.

\section{Introduction}

The U.S. Geological Survey (USGS) completed an assessment of undiscovered, technically recoverable conventional and unconventional (continuous) oil and gas resources within the Tindouf Basin Province of Algeria, Mauritania, Morocco, and Western Sahara (fig. 1). The Tindouf Basin is the westernmost of a series of Paleozoic intracontinental basins that are present across much of northern Africa (Boote and others, 1998; Badalini and others, 2002; Dixon and others, 2017). North Africa was a passive margin in the lower Paleozoic with fluvial systems flowing northwards towards the ocean. Glaciation across North Africa waned in the Ordovician, with meltwater forming a series of north-trending incised valleys that were filled with organic-rich sediments during a major south-directed transgression in the Silurian (Lüning and others, 2000; Le Heron and Craig, 2008). Another major transgression in the Late Devonian led to deposition of a second layer of organic-rich shale (Lüning and others, 2003). These two potential petroleum source rocks form the foundation of the total petroleum systems and assessment units defined and assessed in this study.

\section{Total Petroleum Systems and Assessment Units}

The USGS defined three total petroleum systems (TPS) in the Tindouf Basin Province. The Silurian TPS contains three assessment units (AUs): (1) Tindouf Silurian Shale Gas AU, (2) Tindouf Ordovician Tight Gas AU, and (3) Tindouf Silurian Shale Oil AU. The Devonian TPS contains the (1) Tindouf Devonian Shale Gas AU and (2) Tindouf Devonian Shale Oil AU. The Silurian-Devonian Composite TPS contains the Tindouf Conventional Oil and Gas AU (fig. 1). Silurian shales contain as much as 10 weight percent total

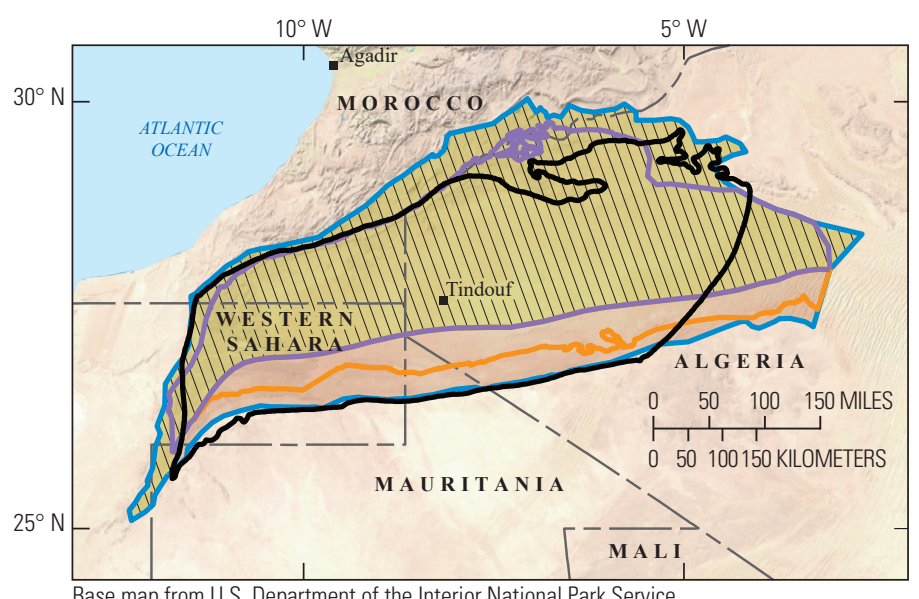

\section{EXPLANATION}

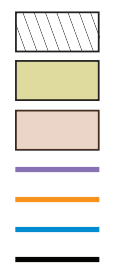
Tindouf Silurian Shale Gas AU Tindouf Ordovician Tight Gas AU Tindouf Silurian Shale Oil AU Tindouf Devonian Shale Gas AU Tindouf Devonian Shale Oil AU Tindouf Conventional Oil and Gas AU Tindouf Basin Province boundary

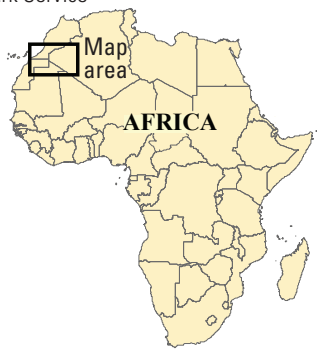

Figure 1. Location of the Tindouf Basin Province, North Africa, and the six assessment units (AUs) defined in this study. organic carbon (TOC), hydrogen index (HI) values as much as 380 milligrams of hydrocarbon per gram of total organic carbon ( $\mathrm{mg} \mathrm{HC} / \mathrm{g} \mathrm{TOC}$ ), and shale thickness is as much as 100 meters (El Diasty and others, 2017). Devonian shales contain as much as 14 weight percent TOC, HI values are as much as $580 \mathrm{mg} \mathrm{HC} / \mathrm{g}$ TOC, and shale thickness is as much as 200 meters (Lüning and others, 2003; Chaouche, 2013).

The geologic model for the Silurian TPS is for oil to have been generated from organic-rich shales possibly as early as the Carboniferous (Lüning and others, 2000), and some of this oil was partially retained within the shales in the southern part of the basin. In the northern part of the basin, oil within the shales cracked to gas during maturation, and some of the gas was retained within the shales. Gas may have migrated locally to accumulate into subjacent tight Ordovician sandstones, forming a potential tight-gas accumulation. The geologic model for the Devonian TPS is similar in that oil as well as gas from thermal cracking of oil was partially retained within Devonian shales following migration. The geologic model for the Silurian-Devonian Composite TPS is for oil and gas from both source rocks to have migrated into conventional traps along the structurally complex northern margin of the basin and into stratigraphic traps within the basin.

Key assessment input data are shown in table 1. Well drainage areas, success ratios, and estimated ultimate recoveries are taken from U.S. shale-oil and shale-gas analogs. For continuous oil and gas accumulations, zeros at F95 reflect the interpretation of geologic risk (AU probability less than 1.0) on the potential occurrence of one well of minimum estimated ultimate recoveries in the AU.

\section{Undiscovered Resources Summary}

The USGS quantitatively assessed undiscovered, technically recoverable oil and gas resources within six assessment units in the Tindouf Basin Province (table 2). The estimated total mean resources are 2,575 million barrels of oil (MMBO), or 2.6 billion barrels of oil, with an F95 to F5 range from 34 to 7,176 MMBO; 123,959 billion cubic feet of gas (BCFG), or 123.9 trillion cubic feet of gas, with an F95 to F5 range from 2,963 to 316,809 BCFG; and 534 million barrels of natural gas liquids (MMBNGL) with an F95 to F5 range from 17 to 1,480 MMBNGL. Of the mean of 2,575 MMBO, 95 percent, or 2,447 MMBO, is continuous oil, and of the mean undiscovered gas resources of 123,959 $\mathrm{BCFG}, 93$ percent, or $114,928 \mathrm{BCFG}$, is continuous gas.

\section{References Cited}

Badalini, G., Redfern, J., and Carr, I.D., 2002, A synthesis of current understanding of the structural evolution of North Africa: Journal of Petroleum Geology, v. 25, no. 3, p. 249-258.

Boote, D.R.D., Clark-Lowes, D.D., and Traut, M.W., 1998, Palaeozoic petroleum systems of North Africa, in MacGregor, D.S., Moody, R.T.J., and Clark-Lowes, D.D., eds., Petroleum geology of North Africa: The Geological Society of London, Special Publications No. 132, p. 7-68

Chaouche, A., 2013, Geological and geochemical attributes of Paleozoic source rocks and their remaining potential for unconventional resources in Erg Oriental Algerian Sahara: American Association of Petroleum Geologists, Search and Discovery Article No. 80313, 34 p., accessed October 23, 2018, at http:/www.searchanddiscovery.com/pdfz/ documents/2013/80313chaouche/ndx_chaouche.pdf.html?q=\%252BauthorStrip $\% 253 \mathrm{Ac}$ haouche+-isMeetingAbstract $\% 253$ Amtgabsyes.

Dixon, R.J., Moore, J.K.S., Bourne, M., Dunn, E., Haig, D.B., Hossack, J., Roberts, N., Parsons, T., and Simmons, C.J., 2017, Integrated petroleum systems and play fairway analysis in a complex Palaeozoic basin — Ghadames-Illizi Basin, North Africa: The Geological Society of London, Petroleum Geology Conference Series, v. 7, p. 735-760. 
Table 1. Key input data for six assessment units (AUs) in the Tindouf Basin Province, North Africa.

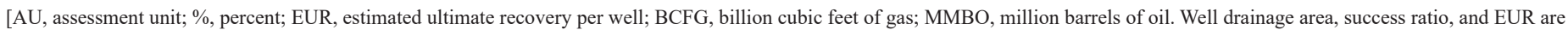
defined partly using U.S. shale-oil and shale-gas analogs. The average EUR input is the minimum, median, maximum, and calculated mean. Shading indicates not applicable]

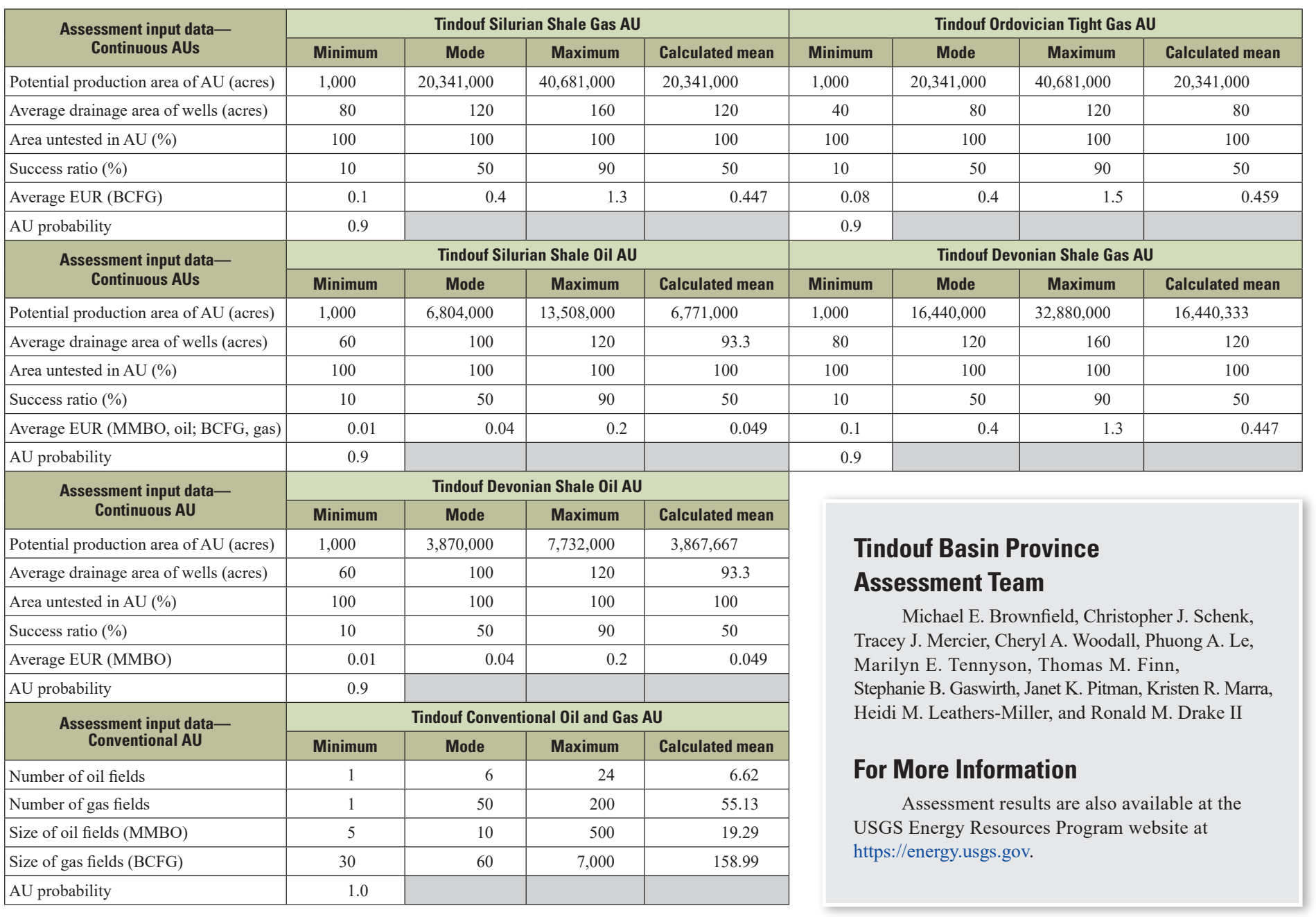

Table 2. Results for six assessment units (AUs) in the Tindouf Basin Province, North Africa.

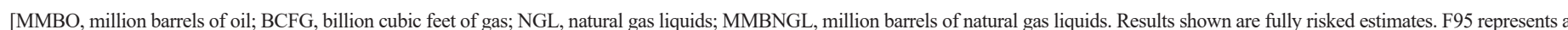

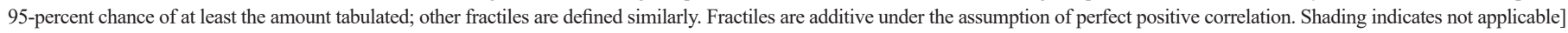

\begin{tabular}{|c|c|c|c|c|c|c|c|c|c|c|c|c|c|c|}
\hline \multirow{3}{*}{$\begin{array}{l}\text { Total petroleum systems } \\
\text { and assessment units (AUs) }\end{array}$} & \multirow{3}{*}{$\underset{\text { probability }}{A U}$} & \multirow{3}{*}{$\begin{array}{c}\text { Accumulation } \\
\text { type }\end{array}$} & \multicolumn{12}{|c|}{ Total undiscovered resources } \\
\hline & & & \multicolumn{4}{|c|}{ Oil (MMBO) } & \multicolumn{4}{|c|}{ Gas (BCFG) } & \multicolumn{4}{|c|}{ NGL (MMBNGL) } \\
\hline & & & F95 & F50 & F5 & Mean & F95 & F50 & F5 & Mean & F95 & F50 & F5 & Mean \\
\hline \multicolumn{15}{|c|}{ Silurian Total Petroleum System } \\
\hline Tindouf Silurian Shale Gas AU & 0.9 & Gas & & & & & 0 & 28,316 & 86,048 & 33,700 & 0 & 103 & 377 & 135 \\
\hline Tindouf Ordovician Tight Gas AU & 0.9 & Gas & & & & & 0 & 42,846 & 138,115 & 52,334 & 0 & 156 & 606 & 209 \\
\hline Tindouf Silurian Shale Oil AU & 0.9 & Oil & 0 & 1,197 & 4,329 & 1,554 & 0 & 698 & 2,650 & 932 & 0 & 11 & 43 & 15 \\
\hline \multicolumn{15}{|c|}{ Devonian Total Petroleum System } \\
\hline Tindouf Devonian Shale Gas AU & 0.9 & Gas & & & & & 0 & 23,027 & 69,694 & 27,425 & 0 & 84 & 307 & 110 \\
\hline Tindouf Devonian Shale Oil AU & 0.9 & Oil & 0 & 682 & 2,528 & 893 & 0 & 399 & 1,554 & 537 & 0 & 6 & 26 & 9 \\
\hline Total undiscovered continuous resources & & & 0 & 1,879 & 6,857 & 2,447 & 0 & 95,286 & 298,061 & 114,928 & 0 & 360 & 1,359 & 478 \\
\hline \multicolumn{15}{|c|}{ Silurian-Devonian Composite Total Petroleum System } \\
\hline \multirow{2}{*}{ Tindouf Conventional Oil and Gas AU } & \multirow{2}{*}{1.0} & Oil & 34 & 100 & 319 & 128 & 62 & 197 & 655 & 256 & 1 & 2 & 7 & 3 \\
\hline & & Gas & & & & & 2,901 & 7,757 & 18,093 & 8,775 & 16 & 45 & 114 & 53 \\
\hline Total undiscovered conventional resources & & & 34 & 100 & 319 & 128 & 2,963 & 7,954 & 18,748 & 9,031 & 17 & 47 & 121 & 56 \\
\hline Total undiscovered resources & & & 34 & 1,979 & 7,176 & 2,575 & 2,963 & 103,240 & 316,809 & 123,959 & 17 & 407 & 1,480 & 534 \\
\hline
\end{tabular}

El Diasty, W.S., El Beialy, S.Y., Anwari, T.A., and Batten, D.J., 2017, Hydrocarbon source potential of the Tanezzuft Formation, Murzuq Basin, south-west Libya-An organic geochemical approach: Journal of African Earth Sciences, v. 130, p. 102-109.

Le Heron, D.P. and Craig, J., 2008, First order reconstructions of a Late Ordovician Saharan ice sheet: Journal of the Geological Society [London], v. 165, no. 1, p. 19-29.
Lüning, S., Adamson, K., and Craig, J., 2003, Frasnian organic-rich shales in North Africa-Regional distribution and depositional model, in Arthur, T.J., MacGregor, D.S., and Cameron, N.R., eds., Petroleum geology of Africa-New themes and developing technologies: The Geological Society of London, Special Publications No. 207, p. 165-184.

Lüning, S., Craig, J., Loydell, D.K., Štorch, P., and Fitches, B., 2000, Lower Silurian 'hot shales' in North Africa and Arabia-Regional distribution and depositional model: Earth Science Reviews, v. 49, nos. 1-4, p. 121-200. 